\title{
The Mistaken Doctrine of CoMmon LAW: A CRitique
}

\section{Lukáš Nikodym ${ }^{1}$, Tomáš Nikodym² ${ }^{2}$ Tereza Pušová ${ }^{3}$}

\begin{abstract}
The study deals with Huerta de Soto's thesis about the "mistaken doctrine of common law", which is based on the equalization of depositum irregulare and mutuum contracts. He concluded that equalization of these contracts resulted in the creation of business cycles. According to this study, Huerta de Soto made a mistake when considering contracts inspired by the continental law based on Roman law. The study shows that mutuum was even in Roman law an ancient contract that was not codified, and that Huerta de Soto's interpretation of this contract in the Anglo-American legal system is based more on civil law, not on common law as he stated in his work. Finally, the problem of common law did not lie in the equalization of the mentioned contracts, but rather in the absence of depositum irregulare contracts applied to monetary questions.
\end{abstract}

\section{Keywords}

Common Law, Roman Law, Business Cycles, Contracts, Law of Bailment

\section{Introduction}

Among many theorists of different economic and legal positions, common law is often considered an efficient legal system providing good protection for property rights. This idea is shared not only among "Posnerian" economists and lawyers, but also among economists in the so-called Austrian tradition. ${ }^{4}$ Also, many authors writing about environmental protection prefer the legal system based on common law to a system of pure legislation. ${ }^{5}$

\footnotetext{
${ }^{1}$ University of Economics in Prague, Department of Economic History, nám. W. Churchilla 4, 13067 Praha 3 , Czech Republic. E-mail: nikodym.lukas@gmail.com.

${ }^{2}$ University of Economics in Prague, Department of Economic History, nám. W. Churchilla 4, 13067 Praha 3 , Czech Republic. E-mail: nikodym.tomas@gmail.com.

${ }^{3}$ University of Economics in Prague, Department of Economic History, nám. W. Churchilla 4, 13067 Praha 3 , Czech Republic. E-mail: pusova.tereza@gmail.com.

${ }^{4}$ Aranson (1992); Rubin (1977); Hayek (1998); Leoni (1972).

${ }^{5}$ Green (1997); Meiners and Yandle (1998).
} 
Historical investigations are often used in support of the common law legal system. Thus the critique of the Spanish economist Jesús Huerta de Soto, writing in the Austrian tradition, is quite unusual. He challenged the proposed efficiency of common law with his thesis about the "mistaken doctrine" that, according to his opinion, resulted in weak property rights protection. His different conclusion about the inefficiency led us to examine his critique more precisely and to solve the possible "dichotomy" between Huerta de Soto and other liberal authors. In our opinion, it is important to verify (or reject) his thesis in order to explain different positions when considering property rights protection in the common law legal system. Thus, we decided to provide a short historical investigation to clarify the contracts and principles used by Huerta de Soto to criticize the efficiency of common law. Huerta de Soto wrote a thesis about the "mistaken doctrine of common law" in his work Money, Bank Credit, and Economic Cycles. ${ }^{6}$ According to Huerta de Soto, the equalization of two different contracts has occurred within common law; namely the depositum irregulare and mutuum contracts, which means deposits on demand and loans. He continued to question the efficiency of common law when compared to Roman law, especially in the area of the protection and enforcement of property rights. As such, this study will analyze his thesis and the question of efficiency. Firstly, Huerta de Soto's approach will be briefly explained. Secondly, the common characteristics of common law and the process of law creation in the Anglo-American legal system, based as it is not only on court decisions, but also on legislation and the assumption of other legal principles, will be described. Thirdly, the issues surrounding the depositum contract assumed from Roman law and the related motivation for signing such contracts will be explained. The question of relevant and adequate alternatives will also be raised. After the description of the contracts assumed from Roman law, the issue of depositum irregulare and mutuum contracts, the process of discovering and implementing contracts, must be resolved and not only within common law, but also within the Roman law which inspired the law of bailments in the AngloAmerican legal system. The very last part of the study involves a summary of the issues connected with the law of bailments and contracts assumed from Roman law into common law and the verification or rejection of the thesis concerning the "mistaken doctrine of common law".

\section{Huerta de Soto's approach to the law \& economics}

According to Huerta de Soto, the equalization of depositum irregulare and mutuum contracts has had significant economic consequences. More precisely, if these legal contracts are equalized when dealing with monetary questions, the equalization leads to business cycles in the manner described by, for example, Ludwig von Mises. ${ }^{7}$ The basic principles of the theory involve artificial credit expansion, which leads to low interest rates and eventually to the incorrect allocation of scarce resources. After his economic analysis of the law, Huerta de Soto concluded that, if the aforementioned contracts are not properly

\footnotetext{
${ }^{6}$ Huerta de Soto (2006).

${ }^{7}$ Mises is the author of the so-called Austrian business cycle theory. He introduced the theory in 1912. For a more precise explanation of the Austrian approach to business cycles, see, for example, Mises (1953); Mises (1998, pp. 535-583); Hayek (1967), and Huerta de Soto (2006).
} 
distinguished, credit expansion will follow and, in the "Austrian tradition", this credit expansion alone is the primary cause of the business cycles. Thus, Huerta de Soto tried to support his theoretical argument with his own historical and legal analysis. However, we are of the opinion that it is possible to identify the main the problem with his work in this very historical analysis. While the legal contracts really exist, their role in the monetary question described by Huerta de Soto and in the historical analysis of business cycles remains questionable.

\section{The inefficiency of Common Law}

In 2006, Jesús Huerta de Soto concluded that the European legal systems based on the tradition of Roman law were more efficient in the area of property right enforcement than the Anglo-American legal system based on the tradition of common law. ${ }^{8}$ His thesis is built on the concept of the equalization of two types of contracts; depositum irregulare and mutuum. The main idea involves the hypothesis that property right transfers have occurred to a greater extent within the framework of the depositum irregulare contract and therefore the bailee has had the right to use the deposit. ${ }^{9}$ For example, former lawyer Theophilus Parsons also made a statement about the inefficiency of the common law, but differently. ${ }^{10}$ He wrote that the common law was in fact an archaic legal system (inadequate) and thus did not correspond to the quick development of society and primarily to international trade at the beginning of the 19 th century. ${ }^{11}$ On the other hand, the common law system also has its advocates, for example, among the "Posnerian" law and economics theorists. ${ }^{12}$

\section{The Anglo-American Legal System}

It would be a mistake to assume that the Anglo-American legal system was only based on common law. Legislation (civil law is of particular importance for this essay) also had its place in this legal system, but the legal principles from continental Europe's legal system (based on the tradition of Roman law) have primarily been adopted. However, the adoption of principles from Roman law (in fact, also the role of legislation) can complicate the confirmation (or refutation) of Huerta de Soto's thesis on inefficiency. The contracts

\footnotetext{
${ }^{8}$ The main difference between these legal systems lies in the way the law is created. The common law system is based on court (judges') decisions. On the other hand, laws in Roman law are "discovered" by lawyers (of course, the role of judges is also appreciable even in this legal system).

${ }^{9}$ Huerta de Soto (2006, pp. 13-20) also shows the economic differences between these two contracts. For example, in the case of depositum irregulare there is no interest paid in contrast with mutuum. The absence of a "deadline" is also very important in the case of depositum irregulare (it is bailment on demand). However, the transfer (or the rate of transfer) of property rights is the most important difference because depositum irregulare only means bailment (with no transfer of property rights to use). On the contrary, in the case of mutuum contracts property rights to use are transferred to the bailee.

${ }^{10}$ Parsons $(1857,1904)$.

${ }^{11}$ Parsons proposed a solution to inefficiency through a greater role for legislation (in fact, that was how laws actually were created in his day).

${ }^{12}$ Peter Aranson (1992) wrote that, according to Richard Posner, allocation efficiency did exist thanks to the common law system (in the private sector). Another theorist, Paul Rubin (1977) designed a model which shows what conditions (litigation participants, their motivation to find a solution, etc.) can lead to utility maximization. The judge in the common law system therefore has the potential to be efficient in the Posnerian perspective.
} 
in the "modern" Anglo-American legal system are in fact a combination of common law, legislation and Roman law, which "was used to fill a gap in the common law". ${ }^{13}$

The case of Coggs v. Bernard ${ }^{14}$ in 1703 can be considered to constitute the beginning of the integration of Roman law principles in the area of bailment law. ${ }^{15}$ Former judge John Holt, inspired by the Roman law contracts, defined the new form of contracts in common law, but the important thing is that the "new" contracts in common law differed from the Roman law pattern and therefore the assumption was not literal. The basic contracts defined by Lord Holt are as follows: depositum, mandatum, commodatum, pignus and locatio. ${ }^{16}$ The differences among the particular types of contracts lie in the different degrees of responsibility (and therefore also in the rate of negligence). The "profitability criterion" is also different. This criterion splits the defined contracts into two groups. In the first group, only one party to the contract can profit, while in the second group both parties to the contract can profit. According to Anglo-American law, only the bailor (the owner) can profit in the case of depositum and mandatum contracts. On the other hand, only the bailee profits in the case of commodatum contracts. However, the important thing is that these contracts are considered to be free and the safekeeping of the deposit therefore has to be free of charge. ${ }^{17}$ In the second group, both parties to the contract can profit. The contracts in this group include pignus and locatio. ${ }^{18} \mathrm{It}$ is important to look more closely at some contracts in accordance with the aforementioned differences among the contracts defined in Roman law and common law.

\section{Depositum and Locatio contracts}

As mentioned above, the depositum contract was implemented in common law as a free contract. Put briefly, it involves a deposit (and bailment) on demand. ${ }^{19}$ Huerta de Soto wrote that "the obligation of the depositor, apart from delivering the goods, is to compensate the depositary for the costs of the deposit." 20 While he also admitted the possibility of a free contract (in situations where the bailee bears the costs of the bailment) in Roman

\footnotetext{
${ }^{13}$ Nestorovska (2005, p. 81).

${ }^{14}$ Jones (1836); Elliot (1914); Carnegie (1967).

${ }^{15}$ Huerta de Soto (2006, p. 124). Other cases mentioned by Huerta de Soto and Murray Rothbard (1994) date from the period after the assumption of the Roman law principles. Specifically, the cases are Carr v. Carr (1811) and Foley v. Hill (1848). Therefore, there is a question as to whether the thesis about the "mistaken doctrine of common law" can be relevant.

${ }^{16}$ Jones (1836). Of course, there were some disputes following the definition of the contracts by Lord Holt. The disputes were about the meaning of particular contracts and also their numbers. Lawyers who participated in the disputes on the Roman law were, for example, J. Godefroi and M. Le Brun. These disputes also then occurred in common law, where, for example, former lawyer and judge, William Jones, argued with the definition of Lord Holt.

${ }^{17}$ Palmer (1975).

${ }^{18}$ Elliott (1914). In the case of locatio contracts, there are four different sub-contracts which distinguish the subject of the contract. This can be, for example, services or transport. According to different subjects, we can find locatio rei, locatio operis faciendi, locatio custodiae and locatio operis mercium vehendarum.

${ }^{19}$ In case of the depositum contract, there is no difference between a Roman law and common law contract when considering the transfer of property rights. Both legal systems considered safekeeping without the use of a deposit as the only possibility.

${ }^{20}$ Huerta de Soto (2006, p. 4).
} 
law, it must be said that this did not become the rule, as was the case in common law. For example, Elliott wrote that "the ordinary expenses incurred in the care of a chattel bailed must be borne by the bailee." 21 The obligation to pay the costs of bailment (by the bailor) therefore only arises in the case of extraordinary expenses. In this situation, the Roman law and common law depositum contracts are different. If only the bailee bears the costs of bailment and if the contract is considered to be a free contract, it is relevant to discuss the motivation to sign such a contract. ${ }^{22}$ In general, it is possible to conclude that contracts where both parties of the contracts can profit will be preferred to contracts where only one party can profit. $^{23}$

The group of contracts where both parties to the contract can profit include pignus and locatio. The pignus contract is, in fact, a pledge and therefore not an adequate alternative to the depositum contract. ${ }^{24}$ The last possible contract according to Holt's definition is therefore the locatio. In general, this involves a lease of items and the division into subcontracts depends on the nature of the item or the service. However, only one sub-contract can be considered a relevant alternative to the depositum contract and that is locatio rei. This type of sub-contract is based on a temporary lease and it is important that there should be compensation for the lease. However, the lease of the item also involves the possibility of using the item and therefore the transfer of property rights is greater in a locatio rei contract than in a depositum contract. ${ }^{25}$ Therefore, from all of the contracts defined by Lord Holt, only the locatio rei contract is an adequate alternative to the depositum contract despite the different (greater) transfer of property rights and even though it is closer to a mutuum contract.

However, there are also other serious issues connected with the depositum contract in the Anglo-American legal system, because it is possible to find contradictory principles applied among court rulings. In the case of Coggs v. Bernard (1703) mentioned above, Holt explained that, if the bailor deposits the deposit locked (or sealed), this implies that he does not have confidence in the bailee and the bailee is therefore not responsible, according to Lord Holt, for any damage or loss of the deposit. ${ }^{26}$ In another later case, Carr v. Carr (1811), mentioned by Rothbard, judge William Grant concluded that, if the deposit is not locked or sealed properly, it cannot be considered to constitute bailment,

\footnotetext{
${ }^{21}$ Elliott (1914, p. 13).

${ }^{22}$ Some cases with application of the free contract principle are described by, for example, Carnegie (1967).

${ }^{23}$ Jones (1836, pp. 113-115). Holt himself presented a few trivial examples to explain free contracts where only one party to the contract can profit. In the case of commodatum contracts, he described a situation where, for example, some tools are lent for free between two friends, and thus only the borrower is able to profit. According to Lord Holt, a mandatum contract means that a service (for example, the transportation of items from place to place) is provided for free. And again, he described this as a situation between two friends where only the owner of the item is able to profit. However, it is hard to imagine that most contracts would be "signed" between friends and for free. For more cases with applied principle of free contracts, see, for example, Palmer (1975).

${ }^{24}$ The subject of the pignus contract is a debt. The liability for this debt involves the pledge of a specific item. However, in terms of the transfer of the property rights, there is no difference between pignus and depositum contracts, because the creditor, like the bailee, can only hold the item, but cannot use the pledge.

${ }^{25}$ Jones (1836). In fact, it is possible to consider locatio rei as commodatum with the possibility of (financial) compensation.

${ }^{26}$ Jones (1836).
} 
but it should be considered to be a loan. ${ }^{27}$ Thus, on the one hand, the lock or seal implied the risk that the bailee would not be responsible for any damage and, on the other hand, the absence of the seal implied that the bailment would not be considered to constitute a depositum.

\section{Depositum irregulare and mutuum contracts}

The issue of a mutuum contract is not only problematic in common law, but also in the Roman legal system. The same holds true for the special depositum irregular contract. Huerta de Soto built his critique on only these contracts. However, it has to be pointed out that certain time discrepancies exist between these contracts. Alan Watson showed that the mutuum contract was considered to be an "archaic" contract even in Roman law. ${ }^{28}$ On the other hand, the depositum irregulare contract is a relatively "young" contract in Roman law. ${ }^{29}$ Also of importance is the fact that it is very hard to find and identify these contracts in common law.

Moreover, the mutuum contract is subject to various explanations of this contract. Elliott wrote that it is a concept used in civil law and that its explanation in common law is considerably different. ${ }^{30}$ While a mutuum contract was considered in civil law to constitute a loan of consumer goods, in common law a mutuum contract was considered to involve a sale. According to civil law, the duty to return goods of the same kind and, of course, quality existed, but it did not have to involve the same goods (the original subject of the contract). In common law, where the mutuum contract is explained as a sale, it is described as a "transfer of the absolute or general property in a thing for a price." 31

Similar to mutuum, the situation is also problematic in the case of depositum irregulare. Elliott realized that in some cases it is very hard to guarantee the return of the identical items that were the subject of the bailment. Similar to Huerta de Soto and Rothbard, Elliott mentioned the case of wheat. In that case, he came to the same opinion, but he highlighted cases where the bailment was not feasible and the case had to be considered a sale, not a bailment. ${ }^{32}$ The same problem was also mentioned by, for example, William Story. ${ }^{33}$ The result was the following: in some cases, it was not possible to define a depositum irregulare

\footnotetext{
${ }^{27}$ Rothbard (1994, p. 42) further quoted judge Grant who noted in the case of Devaynes v. Noble that "money paid into a banker's becomes immediately a part of his general assets; and he is merely a debtor for the amount." ${ }^{28}$ Watson (1984). The first codification of Roman law occurred between 451-450 BC. It is possible to place the mutuum contract in this period. However, it must be pointed out that the contract itself was not codified and that it was replaced with a new "official" contract called the nexum. In the following codifications of Roman law, there is another contract called locatio conductio that also replaced the nexum contract. For another and precise description of different object of particular contracts, see, for example, Villiers (1924).

${ }^{29}$ The depositum irregulare contract was discovered in the period of Ulpian, therefore at the end of the second and the beginning of the third century AD. Huerta de Soto (2006, p. 28) further mentioned that the name depositum irregulare was used for the first time much later - in 1513 in the writings of Jason De Maino.

${ }^{30}$ Elliott (1914, p. 21).

${ }^{31}$ Elliott (1914).

${ }^{32}$ Elliott used the example of processing meat. In the case of processing animals put into bailment (identical animals), it had to be considered a bailment, but when other animals (not identical, but of the same value) were processed it had to be considered a sale.

${ }^{33}$ Story (1856).
} 
contract and therefore a mutuиm contract had to be defined instead. ${ }^{34}$ The precedent court case, closely connected to the issue of depositum irregulare, is Knapp v. Knapp from 1906. During the 19th century, certain liberalization occurred in cases where the subject was the bailment of commutable goods. However, the monetary question, primarily resolved by Huerta de Soto, was ignored for a long time..$^{35}$ The case of Knapp v. Knapp (1906) is therefore revolutionary because the principles of interchangeability were applied to a monetary court case probably for the first time. According to the historical process of discovering the laws described above, it is not possible to talk about monetary depositum irregulare until the beginning of the 20th century. ${ }^{36}$

\section{Contract issues in common law}

A few serious issues can be found in the Anglo-American legal system when dealing with the law of bailment. It is also important to realize that the legal system was not only based on common law principles, but was more a combination of common law, legislation and the assumption of different legal principles, especially from continental European legal systems. This development of the legal system makes the decision (confirmation or refutation) of Huerta de Soto's thesis about a "mistaken doctrine" concerning the equalization of contracts more complicated, especially when we realize that bailment law was largely inspired by Roman law.

Firstly, the depositum contract itself can be considered to be a serious issue, because it was adopted from Roman law as a free contract. Moreover, the cost of safekeeping fell upon the bailee, not the bailor. The motivation to sign such a contract had to be much lower than when signing more preferable contracts. A locatio contract would probably be the preferred document for signing, but, as has been mentioned, it is not a bailment, but a lease. Another issue to the detriment of signing a depositum contract was the existence of contradictory principles applied in various court decisions, because the bailor could not be sure that "the deposit would really constitute a deposit." 37 According to these findings, it is possible to conclude that people would be more motivated to conclude loans and leases than a bailment.

The second serious issue surrounding the Anglo-American legal system can be seen in the dual interpretation of the mutuum contract - in common law and in civil law. The concept of the mutuum contract as described by Huerta de Soto does not correspond to the common legal interpretation, but it corresponds to the civil law interpretation. Despite this issue, the common law mutuum is closely connected to the depositum irregulare contract.

\footnotetext{
${ }^{34}$ In this case, the common law concept of mutuum is meant rather than the civil law concept as described by Huerta de Soto, i.e. the Roman law contract.

${ }^{35}$ For example, in the case of National Corporation for Housing Partnership v. Liberty State Bank from 1987 another case of Wright v. Payne from 1878 is quoted. In the case of Wright v. Payne, the court decided to refuse to apply depositum irregulare principles in a monetary case. It was decided to use the mutuum principles, but when courts were ruling, for example, on wheat (i.e. not on money) in the same period, it is possible to talk about the depositum irregulare principles used by courts.

${ }^{36}$ Elliott (1914), who also quoted the Knapp v. Knapp case, was very skeptical about the use of depositum irregulare principles in monetary cases. In fact, he refused these principles.

${ }^{37}$ See the aforementioned cases of Coggs v. Bernard (1703) and Carr v. Carr (1811).
} 
This is because the mutuum contract has played a significant role in situations where the depositum irregulare has not been defined. ${ }^{38}$ However, the concept of the depositum irregulare was gradually discovered and implemented. This can answer the question posed by Rothbard as to whether there is a difference between cases and verdicts about wheat and money and whether this can be partially caused by a successful "banking lobby" ${ }^{39}$ Of course, it is possible to admit some role for lobbying but the differences between verdicts have been caused more by the slow implementation of the depositum irregulare contract. ${ }^{40}$ In fact, the depositum irregulare contract has led to the slow displacement of the mutuum contract and it is therefore not possible to talk about the equalization of these contracts and as such the thesis about the "mistaken doctrine" is incorrect. The problem of common law does not lie in the equalization of contracts, as written by Huerta de Soto, but more in the absence of the depositum irregulare contract. ${ }^{41}$

\section{Conclusion}

It is ultimately necessary to return to the question of the aforementioned contracts and their link to the creation of business cycles. Although we are of the opinion that a theoretical framework is necessary in order to interpret history (especially economic history), some caution is needed when selecting that framework. It is possible to identify several mistakes in Huerta de Soto's analysis in the selection of the theoretical framework alone. The theory itself, in the tradition of law and economics, is valid and significantly extends the classical economic interpretation first espoused by Mises. However, the contracts used by Huerta de Soto to interpret the principles of the business cycle have been inappropriately selected from the point of view of history. Our analysis shows that the problem of common law does not lie in the inadequate distinction of the crucial contracts, but primarily in the absence of the depositum irregulare contract. If this contract is found at all prior to the beginning of the 20th century, it was not applied to monetary cases, but to other commutable goods, e.g. corn. However, we are of the opinion that there is a simple solution to Huerta de Soto's mistake. It lies in the simplification or more precisely in the generalization of the principles of loans, commutability, etc. By using simplified principles, the problem of the inappropriate use of historical contracts can easily be avoided when creating a theoretical framework to interpret history.

\footnotetext{
${ }^{38}$ As mentioned above, this especially holds for monetary cases.

${ }^{39}$ Rothbard (1994, p. 43).

${ }^{40}$ As mentioned above, Rothbard and Huerta de Soto quoted court cases predominantly from the first half of 19th century. However, the implementation of the depositum irregulare contract into common law is connected more with the end of the 19th and the beginning of the 20th century. In the first half of the 19th century, the contract was applied in only a few cases of commutable goods, e.g. corn. The mutuum contract was still applied in cases involving money.

${ }^{41}$ The absence was thus replaced with the mutuum contract.
} 


\section{References}

Aranson, P. H. (1992). The Common Law as Central Planning. Constitutional Political Economy, 3(3), 289-319.

Carnegie, R. (1967). Bailment and Contract in English Law Today. Adelaide Law Review, 3, 7-17.

Elliott, W. F. (1914). A Treatise on the Law of Bailments and Carriers. Indianapolis: The Bobbs-Merrill Company Publishers.

Green, H. M. (1997). Common Law, Property Rights and the Environment: A Comparative Analysis of Historical Developments in the United States and England and a Model for the Future. Cornell International Law Journal, 30(2), 541-586.

Hayek, F. (1967). Prices and Production. New York: Augustus M. Kelly Publishers.

Hayek, F. (1998). Law, Legislation and Liberty. London: Routledge.

Huerta de Soto, J. (2006). Money, Bank Credit, and Economic Cycles. Auburn: Ludwig von Mises Institute.

Jones, W. (1836). An Essay on the Law of Bailments. Philadelphia: Hogan and Thompson. Leoni, B. (1972). Freedom and the Law. Log Angeles: Nash Publishing.

Meiners, R. Yandle, B. (1998). How the Common Law Protects the Environment: Curbing Pollution Case-by-Case. PERC Reports, 16(2), 5-11.

Mises, L. (1953). The Theory of Money and Credit. New Haven: Yale University Press.

Mises, L. (1998). Human Action: A Treatise on Economics. Auburn: Ludwig von Mises Institute.

Nestorovska, D. (2005). Influences of Roman and Civil Law on the Common Law. Hanse Law Review, 1(1), 79-88.

Palmer, N. (1975). Gratuitous Bailment: Contract or Tort? The International and Comparative Law Quarterly, 24(3), 565-572.

Parsons, T. (1857). The Law of Contracts. Vol. 2. Boston: Little, Brown and Company. Parsons, T. (1904). The Law of Contracts. Vol. 3. Boston: Little, Brown and Company. Rothbard, M. N. (1994). The Case Against the Fed. Auburn: Ludwig von Mises Institute. Rubin, P. H. (1977). Why is the Common Law Efficient? The Journal of Legal Studies, 6(1), 51-63.

Story, W. (1856). A Treatise on the Law of Contracts. Vol. 2. Boston: Little, Brown and Company.

United States Court of Appeals, Eight Circuit. (1987). National Corporation for Housing Partnership v. Liberty State Bank [online]. Retrieved October 27, 2015 from https://law.resource.org/pub/us/case/reporter/F2/836/836.F2d.433.html.

Villiers, M. (1924). Consideration in the Roman Law of Contract. Journal of Comparative Legislation and International Law, 6(1), 120-124.

Watson, A. (1984). The Evolution of Law: The Roman System of Contracts. Scholarly Works Paper 496, University of Georgia School of Law. 